\title{
Real Wages and Non-Traded Goods
}

\author{
Ronald W. Jones \\ University of Rochester
}

Certainly since the time of the famous Stolper-Samuelson article in 1941, much of the literature on the theory of international trade that is concerned with income distribution has focused directly on the impact on real wages made by changes in a country's terms of trade (or tariff-induced changes in domestic prices) in models in which all commodities are traded on world markets. However, one of the principle underlying features of trade among nations is that not all commodities produced in a country have access to world markets, either because of high natural barriers to trade or, increasingly, because of manmade regulations that help to sustain a national market for non-traded goods. The purpose of this note is to examine the similarity, or lack of similarity, in some of the competitive trade models that do allow for non-traded commodities, in the response of real wage rates to disturbances originating abroad (e.g. changes in the terms of trade) and to emphasize the roles of local technology, the pattern of production, and the elasticity in demand behavior, all of which underlie the endogenous response of the real wage rate even in a small open economy.

\section{The Heckscher-Ohlin Model: The Original Setting}

The setting is one in which a small open economy is faced with given world prices for a set, $\mathbf{T}$, of commodities that it would be capable of producing if local factor prices were appropriate given the country's own technology. Of course, if labor and capital, both 
mobile internally between sectors, are the only two inputs utilized in production, with international trade the country is not required to produce more than a pair of these commodities, and one of them could be imported instead of exported. Furthermore, it is assumed that another set of commodities, $\mathbf{M}$, is available in world markets (initially at fixed prices) for consumption, but that regardless of world prices the home country's technology does not allow for their production. Finally, there is another set of commodities that can be produced locally but do not have access to world markets, due to high "trade costs" of some kind, natural or because of government regulations. To simplify matters, I assume that this set consists of a single commodity, $\mathbf{N}$.

It is assumed that an initial equilibrium, with the country producing a pair of traded commodities, is disturbed by a lowering of the world price of one of the commodities in set $\mathbf{M}$, i.e. a commodity that is imported but not capable of being produced at home. Call this commodity 15 . How is the home country's real wage rate affected by such a foreign-sourced improvement in Home's terms of trade? And to what extent is the answer to this query dependent on how large the price fall for commodity 15 is, in particular with reference to any endogenously-determined change in the country's production pattern?

This setting is laid out geometrically in Figure 1. The set, $\mathbf{T}$, is assumed to consist of eight commodities, and the home country's technology, together with the given world prices of these eight commodities, yields the aggregate rising step-function in Figure 1. The traded commodities are numbered in order, with the first commodity being the most labor-intensive. The technology for each commodity indicates that if producers face higher wage/rental ratios, $w / r$, techniques of production would become more capital 
intensive. The mapping of such techniques for each commodity would be monotonically upward sloping. The assumption that traded commodity prices are given reveals that there is only a restrictive range of factor prices for which each commodity would be produced; generally speaking higher wage/rental ratios will call for a switch in production towards more capital intensive commodities. ${ }^{1}$ Flats on this composite schedule represent situations in which a pair of commodities is produced, in which case the given commodity prices for this pair uniquely determine the set of factor prices that will match unit costs to these commodity prices, the zero-profit equilibrium condition for activities that are actually undertaken. A further assumption is made about technology: There is no factor-intensity reversal; the full loci of capital/labor ratios used in one industry never intersect that for any other industry. Finally, the smooth upward-sloping technology contour for the non-traded commodity is assumed to intersect the composite traded locus (at the point, $G$, where both commodity five and six are produced). I discuss the relevance of this assumption below, but it is not based on the intersection of the locus for $N$ with that of any other single locus for a world-traded commodity.

Figure 1 shows the initial equilibrium not only for the home country but also for a foreign country (indicated by an asterisk) that shares the same technology, faces the same set of world prices for traded goods, but has a higher endowment capital/labor ratio. For the moment ignore the situation for the foreign country. Home's overall capital/labor endowment ratio is denoted by $k$, which I assume does not change throughout. In the

\footnotetext{
${ }^{1}$ Given the technology and world prices a set of unit-value isoquants can be displayed in a diagram with capital on the vertical axis and labor on the horizontal. The convex hull of this set, often referred to as the Hicksian composite unit-value isoquant for traded commodities, consists of bowed in sections in which only one commodity is produced, as well as tangent chords along which a pair of commodities is produced. As the economy's ratio of capital to labor devoted to traded goods production increases, production changes towards more capital-intensive commodities. Details of the many-commodity, two-factor Heckscher-Ohlin model were earlier provided in Jones (1974).
} 
initial equilibrium the capital/labor ratio employed in tradeables is indicated by $k_{T}{ }^{0}$, and that for the non-tradeable commodity by $k_{N}{ }^{0}$. Equation (1) shows how the overall capital/labor endowment ratio, assuming full employment, is a weighted average of the ratio used in tradeables and that used to produce non-tradeables:

$$
\lambda_{\mathrm{LN}} \mathrm{k}_{\mathrm{N}}+\lambda_{\mathrm{LT}} \mathrm{k}_{\mathrm{T}}=\mathrm{k}
$$

The weights represent the fractions of the labor force employed in the two sectors. In the traded sector, point $A$ shows that production is positive for both commodities 2 and 3 , and given world prices the factor price ratio is indicated by the flat. At this same factor-price ratio point $B$ illustrates the capital/labor ratio used in the non-traded goods sector.

Whereas points $A$ and $B$ illustrate the techniques used in both sectors as well as the factor-price ratio in the initial equilibrium, points $C, D, E$, and $F$ refer to situations in which the country is completely specialized either in the non-traded goods sector or in non-traded goods. At point $E$ all the economy's factors are used to produce tradeables, in this case a combination of commodities 3 and 4, whereas if they were all used to produce non-tradeables, the wage-rental ratio would be lower, at point $D$, a reflection of the capital-intensity of the non- tradeables sector. Stopping just short of such complete specialization, point $C$ shows that the first commodity would be the only traded good produced if almost all resources were to produce the non-tradeable, whereas the proportions used at $F$ indicate techniques that would be used if only a tiny amount of non-tradeables were produced. 


\section{The Heckscher-Ohlin Model: A Terms-of-Trade Improvement}

The most simple method of examining the effect on Home's real wage rate of an improvement in the terms of trade is to assume that the price of a commodity that is imported but not produced locally (taken as commodity 15 from set $\mathbf{M}$ ) is reduced. In the initial situation the country produces both commodities 2 and 3 (at point $A$ in Figure 1), implying that for small reductions in $p_{15}$ there is no change in the price of the nontradeable commodity (whose production techniques are shown by point $B$ ). The reason, of course, is that factor prices are completely determined by the given prices of commodities 2 and 3, both produced. The outcome is that Home's real wage rate, call it $\omega$, must be improved, assuming labor's taste pattern is assumed to be the same homothetic kind as the country as a whole. With the nominal wage rate, $w$, unchanged, the improvement in the real wage rate reflects the improvement in the cost of living.

The small arrow to the left of point $A$ in Figure 1 suggests that even though a small reduction in $p_{15}$ does not alter nominal factor prices or the pattern of production (Home still produces commodities 2,3 , and $N$ ), it does favor the production of commodity 2 at the expense of commodity 3. This need not be the case, and is the consequence of an arbitrary assumption I have made about demand behavior: A fall in $p_{15}$ affects the country's demand for the non-traded commodity in two different ways. On the one hand, if all commodities are substitutes (i.e. ruling out complementarity in demand) and if real incomes were constant, the demand for $N$ would fall as that for commodity 15 increases. As opposed to this substitution effect, the terms-of-trade inspired improvement in real income encourages a greater demand for commodity $N$. I have arbitrarily assumed here that demand behavior exhibits inelasticity, with income effects outweighing substitution 
effects. That is, the small reduction in $p_{15}$ causes resources, both labor and capital, to be re-allocated to producing more of the non-tradeable commodity to match the increase in demand. $^{2}$ These resources are pulled away from the tradeable sector. Figure 2 provides the details. In the original situation (point $A$ in Figure 1), the outputs of commodities 2 and 3 are shown by vectors $O H$ and $O J$ respectively (Figure 2), with $J G$ parallel to 02 and $G H$ parallel to 03 , with point $G$ indicating the initial resource bundle available for tradeables. $G P$ has been drawn parallel to ray $0 N$, and as resources are drawn away from tradeables towards the non-tradeable good, the bundle of labor and capital available to the traded commodities falls along $G P$, with an asymmetric effect on the production of the pair of tradeables: Production of commodity 3 falls (to zero once point $P$ is reached), while that of the more labor-intensive commodity (2) is increased from initial $O H$ to the level $O P$ when $p_{15}$ has been reduced sufficiently to add $G P$ resources to production of non-tradeables. In terms of equation (1), overall $k$ is constant, as is $k_{N}$. The reduction in $k_{T}$ is matched by the shift in the allocation of labor ( $\lambda_{L N}$ increasing and $\lambda_{L T}$ falling).

Once production in the tradeable sector is focused on a single commodity (2), further improvements in the terms of trade do affect factor prices. As demand for non-tradeables continues to increase, resources cannot be released from commodity 2's production in the proportions required by capital-intensive non-tradeables without forcing a rise in the price of non-tradeables and a consequent lowering of the wage/rental ratio. What happens to the nominal wage rate, $w$ ? The price of tradeable commodity 2 is constant, so that the increase in $p_{N}$ causes rentals to increase and the nominal wage rate to fall. Equations (2) are the competitive profit equations of change for a small further fall in $p_{15}$ that forces an increase in $p_{N}$ :

\footnotetext{
${ }^{2}$ That is, the demand curve for $N$ is assumed to shift rightwards as $p_{15}$ falls.
} 


$$
\begin{aligned}
& \theta_{\mathrm{L} 2} \hat{w}+\theta_{\mathrm{K} 2} \hat{r}=0 \\
& \theta_{\mathrm{LN}} \hat{w}+\theta_{\mathrm{KN}} \hat{r}=\hat{p}_{N}
\end{aligned}
$$

The solution for the change in the nominal wage rate is shown by (3):

$$
\hat{w}=-\left\{\theta_{\mathrm{K} 2} /|\theta|\right\} \hat{p}_{N}
$$

The determinant of factor shares, $|\theta|$, reflects the difference in factor proportions between tradeable commodity 2 and non-tradeable $N,\left(\theta_{\mathrm{L} 2}-\theta_{\mathrm{LN}}\right)$, and is positive. Equation (4) brings together the ingredients that determine the (small) change in the real wage rate when the price of a pure importable, $p_{15}$, falls, when good 2 is the only tradeable commodity produced. Let spending shares on commodity $j$ be given by $\alpha_{\mathrm{j}}$ and let $\omega$ be the real wage.

$$
\hat{\omega}=\alpha_{15}\left(-\hat{p}_{15}\right)-\left\{\alpha_{\mathrm{N}}+\left[\theta_{\mathrm{K} 2} /|\theta|\right]\right\} \hat{p}_{N}
$$

The terms-of-trade improvement, $\left(-\hat{p}_{15}\right)$, helps (but the increase in the price of nontradeables hurts) by lowering the consumer price level. In addition, the decrease in the nominal wage rate, shown in equation (3), likewise tends to lower real wages. The balance, shown in equation (4), could easily work against the interests of labor. However, given that the real wage improved in the initial stage when the price of nontradeables stayed fixed (because two tradeables were being produced), the net outcome for real wages could still be positive. Furthermore,with reference to Figure 1, a sufficient drop in $p_{15}$ could cause production of the first commodity to join that of the second, thus freezing for another interval the price of non-tradeables and encouraging a net improvement in the real wage rate.

The role of shifting production patterns becomes clear in this discussion. It was assumed that initially (at point $A$, Figure 1) Home produces a pair of commodities whose 
world prices are given, thus tying down the wage/rental rate and, as well, the price of non-tradeables. With such a production pattern, the terms-of-trade improvement must, by causing a drop in the consumer price index but without a change in the nominal wage rate, result in an improvement in the real wage rate. It is in ranges in which the economy specializes completely in a traded commodity that the assumed factor-intensity ranking (tradeables labor intensive) easily can work against real wage gains because of its effect on the nominal wage rate. For a country to alter its pattern of production as a consequence of growth or terms-of-trade disturbances is a natural endogenous response in world markets. And such changes lead to possible non-monotonic responses for the real wage rate and other factor prices.

An arbitrary assumption about the nature of demand and the relative strength of income and substitution effects was made in analyzing Home's response in Figure 1 to an improvement in its terms of trade. Return to Home's initial position (point $A$ ) in Figure 1. If its demand pattern exhibited substitution effects stronger than income effects when $p_{15}$ fell, the demand for non-tradeables would fall and, as tradeables receive an infusion of capital and labor in the ratio shown by $G P$ in Figure 2, it is the more capital-intensive tradeable, commodity 3 , that expands and commodity 2's output falls until (with no change in the wage/rental ratio or the nominal wage rate) only commodity 3 is produced for world markets. Further reductions in $p_{15}$ lead to price decreases for the non-tradeable as demand falls and, since $N$ is the relatively capital-intensive commodity, the nominal wage rate increases, supplying a boost to the real wage rate that is additional to that provided by the lowering of an import price. As Figure 1 reveals, a sufficient drop in $p_{15}$ would allow commodity 4 to be produced as well as commodity 3 , freezing the nominal 
wage rate. The extreme point would be shown by point $E$, where tradeables exhaust the economy's factor supplies.

Figure 1 also sets the stage to analyze a country (call it Foreign) facing the same set of world prices, having the same technology (and thus the same aggregate $\mathbf{T}$ schedule in Figure 1), but with a different original endowment bundle and allocation of resources between traded goods and non-traded goods, with initial production of tradeables (commodities 6 and 7 ) at $A^{*}$ and of non-tradeables at point $B^{*}$. In this case if Foreign's income effect in demand is stronger than the substitution effect, so that a drop in $p_{15}$ encourages an inflow of resources to the non-tradeable sector, at first there is no change in the nominal wage rate, but with the traded goods sector becoming more capital intensive ( $N$ 's demand for factors being relatively more heavily weighted to labor than are $T$ 's), Foreign's traded sector becomes completely specialized in the production of commodity 7 , after which further drops in $p_{15}$ cause the nominal (and relative) wage rate to increase because $N$ is relatively labor-intensive. If $p_{15}$ continues to fall, the nominal wage rate continues to increase except for the pause when Foreign produces both commodities 7 and 8 . The limiting case in which almost all resources are devoted to nontradeables (at $D^{*}$ ) would have Foreign producing only commodity 8 in the traded goods sector, just short of point $C^{*}$.

If Foreign demand behavior is different - with the substitution effect of a fall in $p_{15}$ on the market for non-tradeables more powerful than the income effect and a consequent decrease in the demand for non-tradeables, the tradeable goods sector becomes more labor intensive. This favors increased production of commodity 6 (and reduced production of commodity 7), but still keeps nominal factor returns at their initial level. 
This lack of change in wages and rentals reflects the assumption that the initial level of $N$-production is relatively small, with initial traded goods' factor proportions, $k^{0} T^{*}$, close to the endowment ratio, $k^{*}$.

Bringing together the responses of both Home and Foreign to an improvement in their terms of trade reflected in a price fall for a commodity imported but not produced, with both countries sharing the same technology and the same set of prices for commodities produced on world markets, the following conclusions emerge:

(i) The aggregate (or composite) relationship for traded goods response of factor proportions to the prevailing factor-price ratio is a step function with rising parts when only a single traded commodity is produced and flats in situations in which a pair of traded commodities is produced, with the consequence that factor prices are uniquely determined for all points on the flat and, determined as well are the cost and price of the production of a non-traded commodity.

(ii) The rising factor-proportions schedule for the (single) non-traded commodity is assumed to reveal techniques that are relatively capital intensive compared with some of the traded commodities but labor-intensive compared with others. This leads to a form of "factor-intensity reversal" in which for low values of relative wage rates the nontradeable commodity is relatively capital intensive (below intersection point $G$ in Figure 1) and above which $N$ is relatively the labor-intensive sector. ${ }^{3}$ As a consequence two countries may face the same set of world prices for all traded commodities, as well as the same technologies for all locally produced commodities, and yet in the relatively capital abundant country the non-traded good is more labor intensive than any produced traded

\footnotetext{
${ }^{3}$ Note that this relative ranking, in which $N$ is relatively capital intensive at low relative wage rates but relatively labor intensive at high wage rates, cannot be reversed unless $N$ and some individual traded goods exhibit factor-intensity reversals, a condition that is ruled out by assumption.
} 
commodity while such an intensity ranking is reversed in the more labor-abundant, and low wage, country.

(iii) Assuming that of the two countries Home is the low-wage country, with $N$ being relatively capital intensive compared with any produced tradeable and Foreign having $N$ relatively labor intensive compared with any produced tradeable, the consequence for the real wage rate of an improvement in the terms of trade reflected in a lowering of the price of a consumed (but not produced) importable depends on the nature of demand behavior for the non-traded good. At the initial price of non-tradeables the terms-of-trade improvement results in a substitution effect encouraging a leftward shift of the schedule for non-tradeables, while the favorable income effect encourages a rightward shift. If the income effect dominates, as the terms of trade improve resources are transferred towards the non-traded good. If, locally, the country produces a pair of tradeables, no change in the nominal wage rate takes place until and unless the country passes into (or through) a phase in which only one tradeable is produced. If the same pair of tradeables is produced after the (finite) improvement in the terms of trade, the real wage rate must rise since the consumption price index has fallen. However, if the pattern of production does change from its initial value, the nominal wage rate falls in the low-wage Home country and increases in the high-wage Foreign country. At Home, the real wage may fall, depending upon the relative importance of the terms-of-trade improvement as opposed to the increase in the price of non-tradeables. The nominal wage fall at Home makes a drop in the real wage more likely. In Foreign, there is an increase in the nominal wage rate as $p_{N}$ increases and, by Stolper/Samuelson reasoning, the nominal wage rate increases by a 
greater relative amount than does the price of non-tradeables. This, combined with the fall in $p_{15}$, ensures an increase in Foreign's real wage rate.

(iv) The behavior of demand is important:

If income effects in demand for non-tradeables outweigh substitution effects, a favorable terms-of-trade movement increases the real-wage gap between high-wage and low-wage countries. Just the opposite occurs if demand is more elastic such that substitution effects dominate income effects.

In the latter case the (finite) terms-of-trade improvement would support an improvement in nominal and real wage rates in the low-wage Home country and likely reduce them in the high-wage Foreign country. That is, high demand elasticities for non-tradeables encourages a decrease in the real wage gap separating Home and Foreign when both share the same technology and face the same world price fall for one of their importables and the same given world prices for other commodities.

(v) The improvement in the terms of trade would unambiguously improve the real wage rate in both countries if the change in prices does not cause a change in the pattern of production and if originally there is diversified production (in a pair of commodities) in the traded-goods sector.

\section{The Specific Factors Model :}

These results need to be modified somewhat if the production structure for each sector makes use of labor that is homogeneous and mobile among all producing sectors as well as capital that is specific to that sector. In such a case the nominal wage rate changes by a relative amount that is a positive weighted average of relative changes in the prices of all commodities that are locally produced. With exportables fixed in price, 
the relative change in the nominal wage rate is a positive fraction times the relative change in the price of non-tradeables. As in the case of two mobile inputs and a single produced tradeable commodity, the factor intensity ranking between non-tradeables and exportables is important, but not to the extent it is in the $2 \times 2$ case. Instead, any increase in the price of non-tradeables results in a positive fractional relative increase in the nominal wage rate, but the fraction is larger the more labor-intensive is the non-tradeable sector compared with endowment proportions. ${ }^{4}$ Two other features of the technology for non-tradeables are also relevant: (i) the elasticity of the demand for labor in nontradeables relative to the national average over both industries, and (ii) the relative importance in the overall national income of each industry. Let $\theta_{\mathrm{N}}$ denote the share of $N$ in aggregate produced income, $i_{N}$ the relative labor-intensity in producing non-tradeables, and $s_{N}$ the relative elasticity of demand for labor in non-tradeables. ${ }^{5}$ Then

$$
\hat{w}=\theta_{\mathrm{N}}\left\{\mathrm{i}_{\mathrm{N}} \mathrm{S}_{\mathrm{N}}\right\} \hat{p}_{N}
$$

where a hat over a variable denotes a relative change in that variable. The expression in brackets is called the intensity-elasticity nugget. ${ }^{6}$ If labor has the same taste patterns as all members of the economy, the change in its cost-of-living index, $p$, is shown by:

$$
\hat{p}=\alpha_{N} \hat{p}_{N}+\alpha_{15} \hat{p}_{15}
$$

\footnotetext{
${ }^{4}$ In the $2 \times 2$ Heckscher-Ohlin model, by contrast, the change in the wage/rental ratio is relatively larger the closer are factor intensities, although for a finite commodity price change the greater is the possibility of the country becoming completely specialized.

${ }^{5}$ As shown in Caves, Frankel and Jones (2007), pp. S 20-21, $i_{N}$ is the term $\lambda_{\mathrm{LN}} / \theta_{\mathrm{N}}$, the ratio of the fraction of the economy's labor force used to produce $N$, to the share such production represents of gross production, $\theta_{\mathrm{N}}$, and $s_{N}$ is the ratio of the elasticity of demand for labor in the $N^{\text {th }}$ sector, $\gamma_{\mathrm{LN}}$ (i.e. the elasticity of the marginal product of labor in that sector), compared to the overall aggregate elasticity of demand for labor, $\gamma_{\mathrm{L}}$, which is $\lambda_{\mathrm{LN}} \gamma_{\mathrm{LN}}+\lambda_{\mathrm{LT}} \gamma_{\mathrm{LT}}$.

${ }^{6}$ See Jones and Ruffin (2008). Whereas rankings of factor substitutabilities matter in the specific-factors model, along with factor intensities, they do not in the Heckscher-Ohlin model.
} 
where $\alpha_{\mathrm{j}}$ represents the share of the $\mathrm{j}^{\text {th }}$ commodity in aggregate consumption. With the share of non-tradeables in production and consumption the same, the term for the relative change in the real wage rate is:

$$
\hat{\omega}=\theta_{\mathrm{N}}\left[\mathrm{i}_{\mathrm{N}} \mathrm{S}_{\mathrm{N}}-1\right] \hat{p}_{N}+\alpha_{15}\left(-\hat{p}_{15}\right)
$$

A comparison of this expression with that shown in equation (4) reveals that the role for factor intensity comparisons between the Heckscher-Ohlin model and the SpecificFactor model differs. If the intensity-elasticity nugget is close to unity, i.e. production techniques are on average similar in the two producing sectors, the real wage must increase in the specific-factors setting because the effect of the price change on the nominal wage just matches the cost-of-living adjustment. By contrast, in equation (4) the direction of change of the price of non-tradeables depends upon the factor-intensity ranking.

\section{The Middle Products Setting:}

A final setting in which to pose the question as to the effect on the real wage rate of an improvement in a country's terms of trade is provided in the "middle products" approach described in Sanyal and Jones (1982). The core idea of that model is that there is a series of productive activities whereby productive resources and raw materials are transformed into final commodities ready for consumption, and that the role of international trade is to convert products available in early stages of production into a different array of products more useful as inputs into the process by which final consumer goods are made available. That is, international trade takes place in the "middle" of the production process. The Input Tier involves adding value to local resources to produce a set of "middle products", 
which then get traded for other middle products to be used as inputs in the Output Tier of the economy, the tier producing final consumer goods.

To address the issue of the impact of an improvement in the terms of trade on the real wage rate, I simplify the middle products setting in the following ways: There is only one productive activity in the Input Tier: There is a specific factor, $V_{B}$, that is combined with labor $\left(L_{I}\right)$ to produce an amount of commodity $B$. This quantity is exchanged in world markets for a similar value of commodity $A$, a different middle product which is then combined with labor $\left(L_{O}\right)$ in the Output Tier to produce a single non-traded commodity, $x_{N}$. From an initial equilibrium there is an improvement in Home's terms of trade reflected in a lowering of the world price of $A, \hat{p}_{A}$.

The final price of non-tradeables, $p_{N}$, is matched by the cost of production, as in (8):

$$
\mathrm{a}_{\mathrm{LN}} w+\mathrm{a}_{\mathrm{AN}} p_{A}=p_{N}
$$

For small drops in the price of middle product $A$, the competitive profit equations of change are shown in equation (9):

$$
\theta_{\mathrm{LN}} \hat{w}+\theta_{\mathrm{AN}} \hat{p}_{A}=\hat{p}_{N}
$$

The change in the nominal wage rate is the amount that serves to clear the economy's labor market, with a fixed overall quantity of labor:

$$
\lambda_{\mathrm{LI}} \hat{L}_{I}+\lambda_{\mathrm{LO}} \hat{L}_{o}=0
$$

Assuming the world price of middle product $B$ is unchanged, the elasticity of demand for labor in the Input Tier is by definition given by equation (11):

$$
\hat{L}_{I}=-\gamma_{\mathrm{LI}} \hat{w}
$$

In the Output Tier a single non-traded commodity is produced, using $A$ and $L_{O}$. The amount of labor used in the Output Tier is $\left(a_{L N} x_{N}\right)$. A pair of equations of change can be 
used to solve separately for the change in the quantity of labor used in producing a unit of $N^{7}$. They yield as a solution (with $\sigma_{\mathrm{N}}$ denoting the elasticity of substitution in producing $N)$ :

$$
\hat{a}_{L N}=-\theta_{\mathrm{AN}} \sigma_{\mathrm{N}}\left(\hat{w}-\hat{p}_{A}\right)
$$

With $\hat{L}_{0}$ equal to $\left(\hat{a}_{L N}+\hat{x}_{N}\right)$, substitution of these expressions of change into equation (10) leads to the following solution for the change in the nominal wage rate:

$$
\hat{w}=\left\{\lambda_{\mathrm{LO}} \theta_{\mathrm{AN}} \sigma_{\mathrm{N}} /\left[\lambda_{\mathrm{LO}} \theta_{\mathrm{AN}} \sigma_{\mathrm{N}}+\lambda_{\mathrm{LI}} \gamma_{\mathrm{I}}\right]\right\} \hat{p}_{A}+\left\{\lambda_{\mathrm{LO}} /\left[\lambda_{\mathrm{LO}} \theta_{\mathrm{AN}} \sigma_{\mathrm{N}}+\lambda_{\mathrm{LI}} \gamma_{\mathrm{I}}\right]\right\} \hat{x}_{N}
$$

Note the coefficient of $\hat{p}_{A}$ on the right-hand side. It is a positive fraction. With $\hat{p}_{A}$ negative, it means that discounting any income effect the nominal wage rate also falls, but not as much as does $\hat{p}_{A}$. From relationship (9) this implies that the price of nontradeables must also fall, and with $\hat{p}_{N}$ being a weighted average of $\hat{w}$ and $\hat{p}_{A}$ the nominal wage rate does not fall as much as the price of non-tradeables. Hence if income effects are not included, the real wage rate must increase despite a fall in the nominal wage. The terms of trade have improved, and this must find expression in an increase in $x_{N}$, which serves further to increase the real wage rate. Indeed, it may result in an increase in the nominal wage rate as well.

The initiating fall in $p_{A}$ induces a change in techniques used in the Output Tier to produce the final non-tradeable, $N$. There is substitution against labor, so that some labor is shifted to the Input Tier, which serves to drive down the nominal wage rate, although this decrease cannot be as large as the subsequent fall in the price of producing nontradeables. The fact that middle product $A$ has been imported means that real incomes at

\footnotetext{
${ }^{7}$ The first equation states that the relative change in costs is zero at the point of cost minimization, while the second defines the elasticity of substitution in producing $N$. Details are found in Caves, Frankel, and Jones (2007), pp. S 23,24.
} 
Home have improved, and this implies greater consumption of non-tradeables, produced in the Output Tier. Thus not so much labor gets transferred to the Input Tier, and, indeed, there may be a net movement of labor into the Output Tier. (This again pits a substitution effect - away from labor's use as an input in the Output Tier -against an income effect a higher production of non-tradeables in the Output Tier). In such a case the nominal wage rate increases. In any case the nominal wage rate cannot fall by as much as the price of non-tradeables, so that the real wage rate must increase. With only one commodity $(N)$ being consumed in this description, there is no room for a demand relationship between two consumed items to play a role in the effect of a terms-of-trade improvement on the real wage rate. ${ }^{8}$

\section{Concluding Remarks:}

Three scenarios have been selected in which to raise the question: What is the impact of a favorable movement in a country's terms of trade on the real wage rate? Not surprisingly, this change could easily be of either sign in a Heckscher-Ohlin setting, depending upon the labor-intensity ranking. For small changes, if two tradeables are produced at given world prices, there is no change in the nominal wage rate. The magnification effect found in Heckscher-Ohlin settings implies that if only one tradeable is produced, the change in the nominal wage rate either exceeds both commodity price changes (traded and non-traded) or is lower than both. By contrast, in the SpecificFactors setting with labor the mobile factor, the nominal wage change is a positive weighted average of commodity price changes. Despite the magnified response of the

\footnotetext{
${ }^{8}$ The model could be changed slightly in allowing Home's exports of middle product $B$ to be balanced by imports not only of $A$ but also of another middle product, $C$, which is used to produce a different final, nontradeable, perhaps without requiring any additional labor in the Output Tier.
} 
nominal wage change in the Heckscher-Ohlin setting for small changes in relative commodity prices, larger changes encourage a change in the pattern of production from one commodity to another, with an intermediate range in which two commodities are produced during which there is no change in the nominal wage rate. In such ranges there is nonetheless a continuing fall in the price of importables, which, by lowering the cost of living to labor, serves to encourage an improvement in the real wage rate. That is, even if factor-intensity rankings in production and the nature of demand conditions conspire to lower the nominal wage rate when only a single tradeable good is produced, there are periods in which tradeable production is diversified during which the real wage rate is temporarily improved by the reduction in the consumer price index. Demand conditions have a role to play in addition to that of factor intensities in that the fall in the price of a consumable import commodity may encourage more resources to go into the production of the non-tradeable (if income effects dominate substitution effects in demand) or to move out of non-tradeables otherwise.

Comparing two countries that share the same technology and world market prices as well as taste patterns, but with non-tradeables being relatively capital intensive in a lowwage Home country and labor-intensive in a high-wage Foreign country, the real wage gap separating countries would become more pronounced if they face a fall in the price of a non-produced importable and demand conditions are inelastic, and the gap would be narrowed if substitution effects dominate income effects in demand.

In specific-factor settings an improvement in the terms of trade is shown to be more apt to lead to improvements in the real wage rate as well, especially if the factor intensity and labor demand elasticities are fairly similar between tradeables and non-tradeables. 
This optimistic forecast for a real wage improvement is even more likely in a MiddleProducts scenario, which is based on the specific-factor setting. 


\section{References:}

Caves, Richard E., Ronald W. Jones and Jeffrey A. Frankel (2007): World Trade and Payments, $10^{\text {th }}$ edition, (Addison-Wesley, Boston).

Jones, Ronald W. (1974): “The Small Country in a Many-Commodity World," Australian Economic Papers, vol. 13, pp. 225-36, reprinted as Ch. 2 in R. Jones, 1979, International Trade: Essays in Theory (North-Holland, Amsterdam). and Roy J. Ruffin (2008): "Trade and Wages: A Deeper Investigation", forthcoming, Review of International Economics.

Sanyal, Kalyan and Ronald W. Jones (1982): “The Theory of Trade in Middle Products," American Economic Review, vol. 72, pp. 16-31.

Stolper, Wolfgang and Paul A. Samuelson (1941): "Protection and Real Wages," Review of Economic Studies, vol. 9, pp. 58-73. 


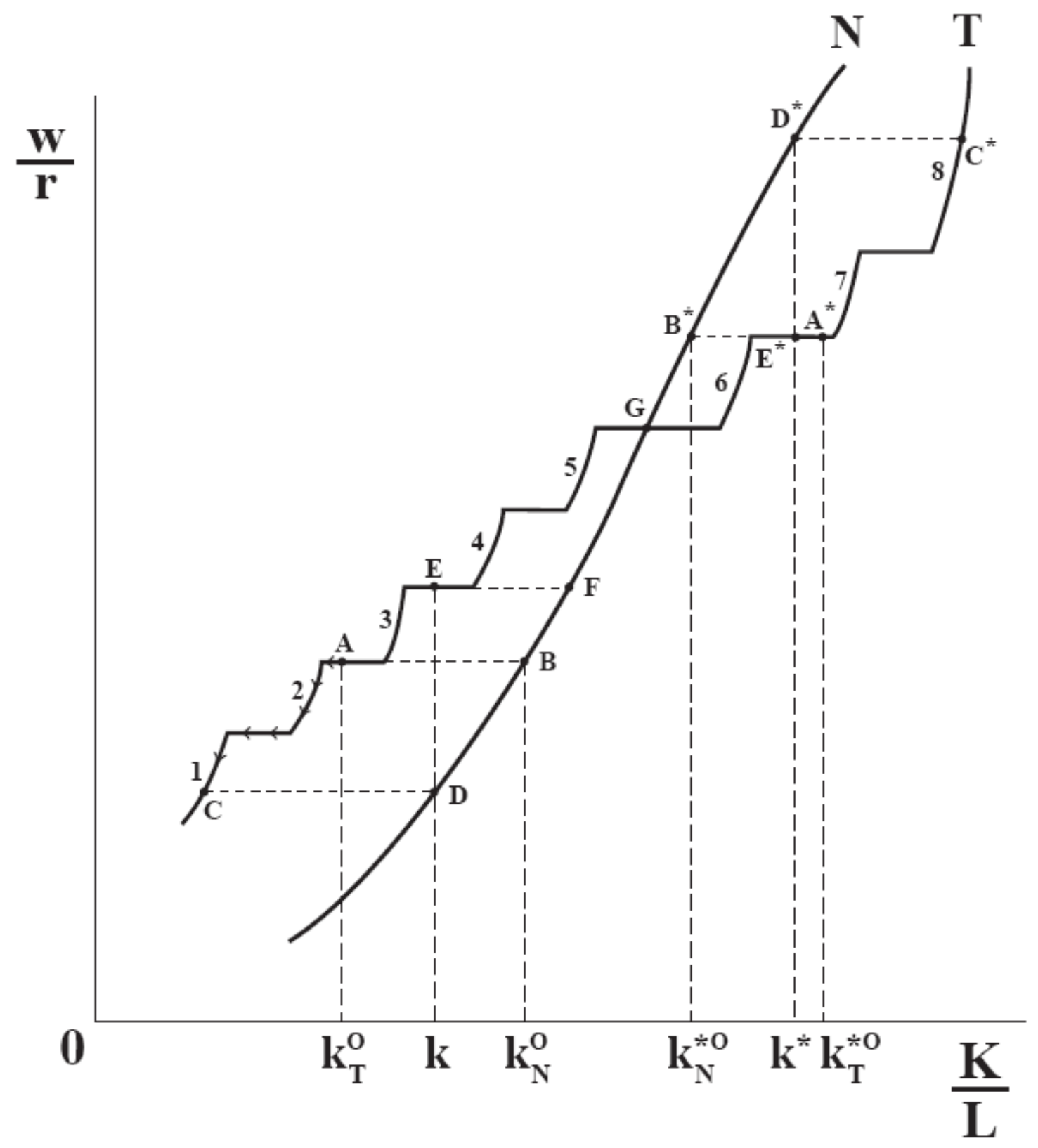

Figure 1: Traded and Non-traded Commodities 


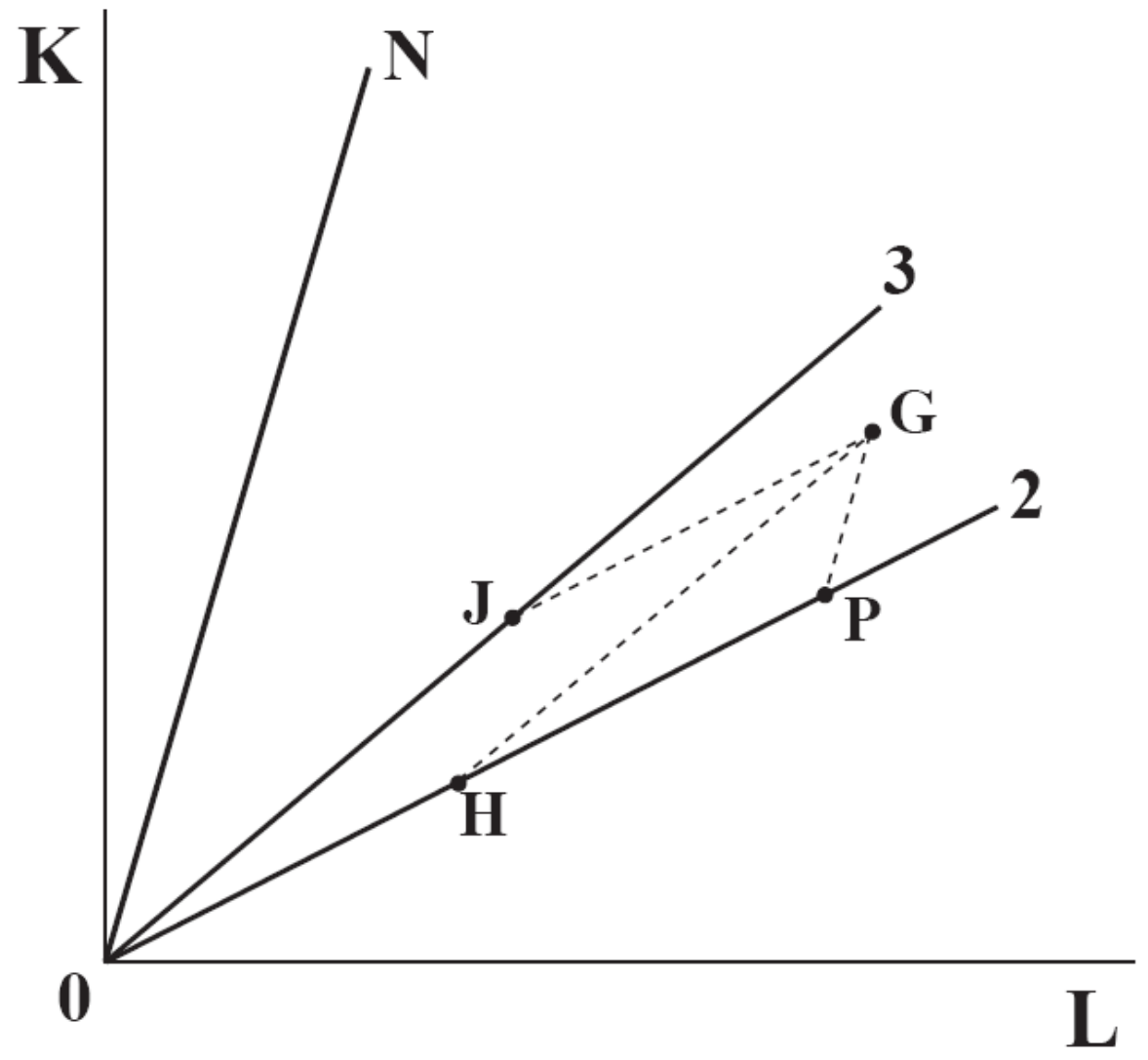

Figure 2: Resource Transfer towards Non-Tradeables 